\title{
Response to Comment on "Prognostic Role of Claudin-1 Immunohistochemistry in Malignant Solid Tumors: A Meta-Analysis"
}

\author{
Jung-Soo Pyo, Nae Yu Kim¹, Won Jin Cho ${ }^{2}$ \\ Departments of Pathology and 'Internal Medicine, Eulji University Hospital, Eulji University School of Medicine, Daejeon; \\ 2Department of Urology, Chosun University Hospital, Chosun University School of Medicine, Gwangju, Korea
}

This study aimed to elucidate the prognostic roles of claudin-1 immunohistochemistry in various malignant tumors through a meta-analysis. Data from all included studies were extracted by two independent authors (J.S.P. and N.Y.K.). Any disagreements for extracting data were resolved by consensus. In the present study, to review more articles, we used the narrow exclusion criteria. Therefore, discordance for the literature collection did not occur. We assessed the risk of bias for all included studies according to the Newcastle-Ottawa Scale. The detailed information was shown in Table 1. All data for survivals were a 5-year survival rate. If the extractable data only included the survival curve, survival rates at 5 -year were obtained from the survival curve.

\section{ORCID}

Jung-Soo Pyo: https://orcid.org/0000-0003-0320-8088

Nae Yu Kim: https://orcid.org/0000-0002-0461-6385

Won Jin Cho: https://orcid.org/0000-0001-9827-5173

\section{Conflicts of Interest}

The authors declare that they have no potential conflicts of interest. 


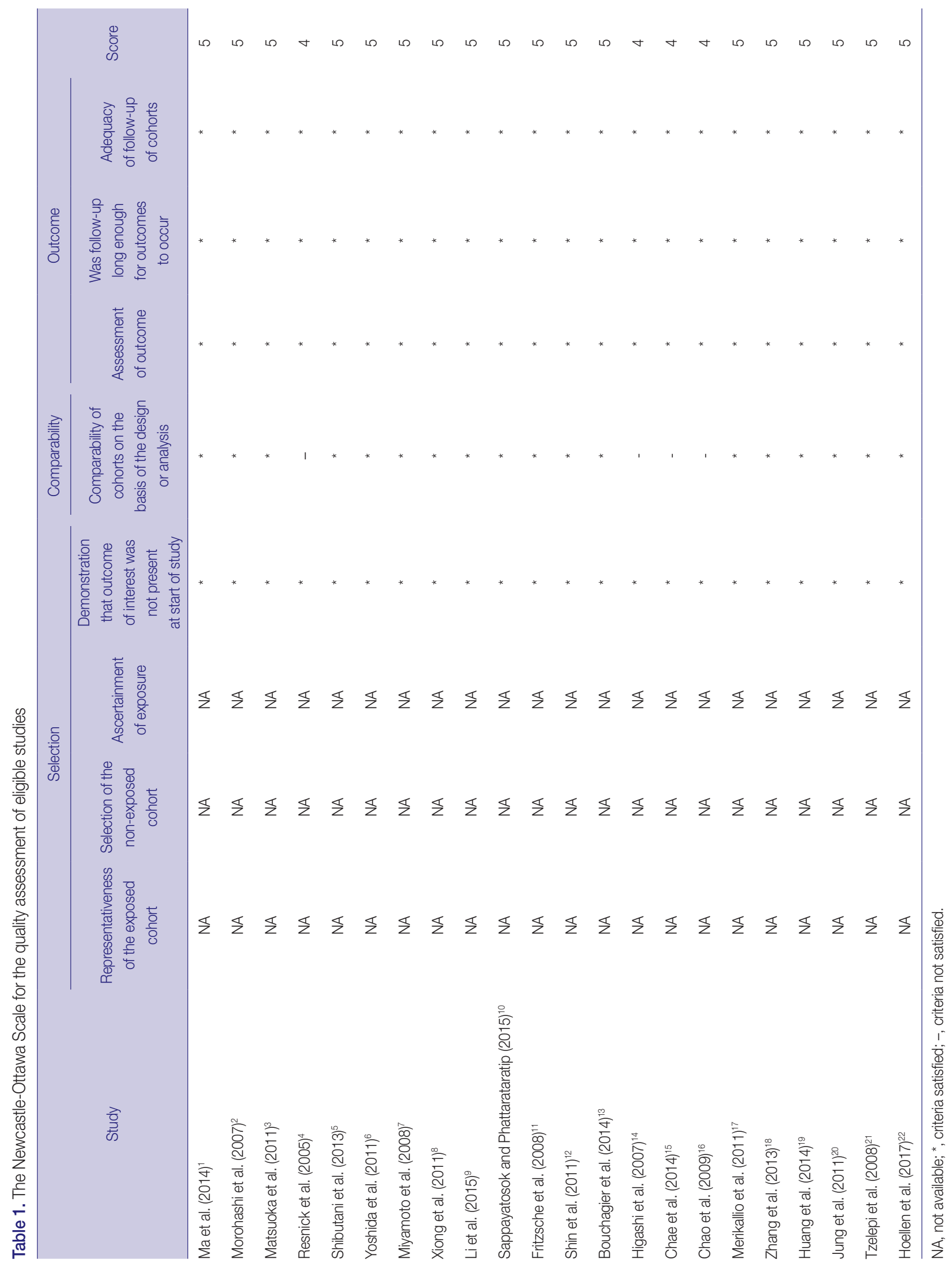




\section{REFERENCES}

1. Ma F, Ding X, Fan Y, et al. A CLDN1-negative phenotype predicts poor prognosis in triple-negative breast cancer. PLoS One 2014; 9: e112765.

2. Morohashi S, Kusumi T, Sato F, et al. Decreased expression of claudin-1 correlates with recurrence status in breast cancer. Int J Mol Med 2007; 20: 139-43.

3. Matsuoka T, Mitomi H, Fukui N, et al. Cluster analysis of claudin-1 and -4 , E-cadherin, and beta-catenin expression in colorectal cancers. J Surg Oncol 2011; 103: 674-86.

4. Resnick MB, Konkin T, Routhier J, Sabo E, Pricolo VE. Claudin-1 is a strong prognostic indicator in stage II colonic cancer: a tissue microarray study. Mod Pathol 2005; 18: 511-8.

5. Shibutani M, Noda E, Maeda K, Nagahara H, Ohtani H, Hirakawa K. Low expression of claudin-1 and presence of poorly-differentiated tumor clusters correlate with poor prognosis in colorectal cancer. Anticancer Res 2013; 33: 3301-6.

6. Yoshida T, Kinugasa T, Akagi Y, et al. Decreased expression of claudin-1 in rectal cancer: a factor for recurrence and poor prognosis. Anticancer Res 2011; 31: 2517-25.

7. Miyamoto K, Kusumi T, Sato F, et al. Decreased expression of claudin-1 is correlated with recurrence status in esophageal squamous cell carcinoma. Biomed Res 2008; 29: 71-6.

8. Xiong L, Wen Y, Miao X, Yang Z. Expressions of cell junction regulatory proteins and their association with clinicopathologic parameters in benign and malignant gallbladder lesions. Am J Med Sci 2011; 342: 388-94.

9. Li WJ, Zhang ZL, Yu XM, Cai XL, Pan XL, Yang XY. Expression of claudin-1 and its relationship with lymphatic microvessel generation in hypopharyngeal squamous cell carcinoma. Genet Mol Res 2015; 14: 11814-26.

10. Sappayatosok K, Phattarataratip E. Overexpression of claudin-1 is associated with Advanced clinical stage and invasive pathologic characteristics of oral Squamous Cell Carcinoma. Head Neck Pathol 2015; 9: 173-80.

11. Fritzsche FR, Oelrich B, Johannsen M, et al. Claudin-1 protein ex- pression is a prognostic marker of patient survival in renal cell carcinomas. Clin Cancer Res 2008; 14: 7035-42.

12. Shin HI, Kim BH, Chang HS, Kim CI, Jung HR, Park CH. Expression of claudin-1 and -7 in clear cell renal cell carcinoma and its clinical significance. Korean J Urol 2011; 52: 317-22.

13. Bouchagier KA, Assimakopoulos SF, Karavias DD, et al. Expression of claudins- $1,-4,-5,-7$ and occludin in hepatocellular carcinoma and their relation with classic clinicopathological features and patients' survival. In Vivo 2014; 28: 315-26.

14. Higashi Y, Suzuki S, Sakaguchi T, et al. Loss of claudin-1 expression correlates with malignancy of hepatocellular carcinoma. J Surg Res 2007; 139: 68-76.

15. Chae MC, Park CK, Keum DY, Hwang I, Kwon KY, Jang BC. Prognostic significance of claudin 4 in completely resected adenocarcinoma of the lung. Korean J Thorac Cardiovasc Surg 2014; 47: 262-8.

16. Chao YC, Pan SH, Yang SC, et al. Claudin-1 is a metastasis suppressor and correlates with clinical outcome in lung adenocarcinoma. Am J Respir Crit Care Med 2009; 179: 123-33.

17. Merikallio H, Kaarteenaho R, Pääkkö P, et al. Impact of smoking on the expression of claudins in lung carcinoma. Eur J Cancer 2011; 47: $620-30$

18. Zhang Z, Wang A, Sun B, Zhan Z, Chen K, Wang C. Expression of CLDN1 and CLDN10 in lung adenocarcinoma in situ and invasive lepidic predominant adenocarcinoma. J Cardiothorac Surg 2013; 8: 95.

19. Huang J, Li J, Qu Y, et al. The expression of claudin 1 correlates with beta-catenin and is a prognostic factor of poor outcome in gastric cancer. Int J Oncol 2014; 44: 1293-301.

20. Jung $\mathrm{H}$, Jun $\mathrm{KH}$, Jung JH, Chin HM, Park WB. The expression of claudin-1, claudin-2, claudin-3, and claudin-4 in gastric cancer tissue. J Surg Res 2011; 167: e185-91.

21. Tzelepi VN, Tsamandas AC, Vlotinou HD, Vagianos CE, Scopa $\mathrm{CD}$. Tight junctions in thyroid carcinogenesis: diverse expression of claudin-1, claudin-4, claudin-7 and occludin in thyroid neoplasms. Mod Pathol 2008; 21: 22-30.

22. Hoellen F, Waldmann A, Banz-Jansen C, et al. Claudin-1 expression in cervical cancer. Mol Clin Oncol 2017; 7: 880-4. 